\title{
Characterisation of Polymesoda bengalensis Shell Powder
}

\author{
Mahshuri Yusof ${ }^{\mathrm{a}, *}$, Nur Tahirah Razali ${ }^{\mathrm{a}}$, Marini Sawawi ${ }^{\mathrm{a}}$, Nicholas Kuan Hoo Tien ${ }^{\mathrm{a}}$ and \\ Dexter Sigan anak John ${ }^{\mathrm{b}}$ \\ ${ }^{a}$ Department of Mechanical and Manufacturing Engineering, Faculty of Engineering, \\ ${ }^{b}$ Faculty of Language and Communication, \\ Universiti Malaysia Sarawak, 94300 Kota Samarahan, Sarawak, Malaysia
}

\begin{abstract}
Seafood shell is abundant and has no eminent use and thus, commonly regarded as waste. Reusing and converting it into a useful material can decrease the amount of waste. Therefore, a study of the crystalline structure should be performed before identifying the potential use of the material. The aim of this study is to identify the element and polymorph of Polymesoda bengalensis shell. The characterisations involved the usage of X-ray powder diffraction (XRD), scanning electron microscope (SEM) and energy-dispersive X-ray spectroscopy (EDX). The XRD study revealed that the shell powder mostly consisted of aragonite. The analysis from SEM also revealed that the aragonite was in the form of rod-like crystal. The morphology of sectional, inner and outer surfaces of the shell was s found that the aragonite was arranged in the form of a cross-lamellar structure of various sizes. The elemental content of the shell showed that $\mathrm{CaCO}_{3}$ in this shell contained large amounts of calcium and carbon.
\end{abstract}

Keywords: Polymesoda bengalensis, Clam Shell, Polymorph; Aragonite.

\section{Introduction}

Calcium carbonate $\left(\mathrm{CaCO}_{3}\right)$ can be obtained either by mining processes from limestone or from biological resources such as seashells and eggshells. Its powder is mostly used in industrial applications such as paper, inks, plastics and medicines [1]. In composite production, $\mathrm{CaCO}_{3}$ is one of the widely used fillers infused in the plastics matrix composite [2].

Basically, $\mathrm{CaCO}_{3}$ has three types of polymorph: calcite, aragonite and vaterite [3]. Commercial $\mathrm{CaCO}_{3}$ from limestone is in the form of calcite[4]. Calcite can be found in Strombidae shell such as Crassostrea gigas [5] and Strombus gigas [6], and at the outer layer of several bivalves [7, 8], such as Pterioida and Mytiloida [9, 10]. Natural aragonite is of biogenic origin and it is denser than calcite.. Due to its higher density and biocompatibility, aragonite is suitable for producing scaffold to repair fractured bone [11]. It can also be produced in the lab but in a small quantity [12]. Vaterite is a metastable $\mathrm{CaCO}_{3}$ that has been detected in the upper layer and at the surface of freshwater cultured pearls [13]. Currently, calcium carbonate polymorph can be synthesised in the lab under a controlled environment in terms of, for example, temperature [14] and chemical solution [15].

This research investigates the characteristics of Polymesoda bengalensis shell and its powder. The findings from this research is beneficial for industrial application such as in wastewater treatment and biomaterial. The finding is also provide a green resource due to the conversion of waste to a

\footnotetext{
* Corresponding author. Tel.: +60-82-583289; fax: +60-82-583410

E-mail address: ymashun@unimas.my

Manuscript History:

Received 22 April 2020, Revised 30 April 2020, Accepted 30 April 2020, Published 30 April 2020
}

e-ISSN: 2289-7771 
useful product. In addition, the use of $\mathrm{CaCO}_{3}$ derived from local seafood shell waste may reduce the amount of waste in the landfill and the dependence on $\mathrm{CaCO}_{3}$ resources from limestone quarries.

In Malaysia, edible brackish water bivalves are on the top list of the major seafood production (54\%), followed by shrimp (17.3\%) and marine fish (6.3\%) [16]. Among the edible bivalves are Polymesoda bengalensis from the Corbiculidae family. The sample of Polymesoda bengalensis used for this study was collected from Kota Samarahan, Sarawak. [17]. It was distributed in the mangrove and muddy areas in the maximum divisions of Sarawak, the biggest state in Malaysia. The shell is dark green, hard and thick, and it is sub-trigonal in shape with eroded umbo. Polymesoda spp. provides a cheap protein source [17] and can grow up to $10 \mathrm{~cm} \mathrm{[18].} \mathrm{By} \mathrm{far,} \mathrm{there} \mathrm{is} \mathrm{no} \mathrm{official}$ documentation on the characterisation of this clam shell and its usage. In Malaysia, most of the researches on molluscshas only focused on cockles Anadara granosa [4, 19], Perna viridis [20] and razor clam [21,22]. Most of the literature reported on the utilisation its body tissue as biomonitors for heavy metal at estuaries and in coastal water [23]. Other countries such as Japan, South Korea and United Kingdom convert the disposed oyster shell to be fertilizer, food additive and natural mineral supply [24, 25].

Table 1 shows a comparison of the polymorphs of other mollusc shells studied by other researchers with Polymesoda bengalensis. Islam et al.[4] found that there were other trace elements such as Aluminium, Copper and Tellurium present in Anadara granosa shell powders after the powders were sieved with aperture size of $90 \mu \mathrm{m}$. Compared to Anadara granosa, Polymesoda bengalensis does not contain any trace elements in the powder when it passed through a $63 \mu \mathrm{m}$ sieve. Strombus gigas Linnaeus shell from a family of Strombidae largely contained aragonite. On the other hand, calcite was only found at the outmost layer of the Strombus gigas shell.

Table 1. Polymorph of different species of bivalve shells.

\begin{tabular}{|c|c|c|}
\hline Polymorph & Family & Species \\
\hline \multirow[t]{4}{*}{$\begin{array}{l}\text { Entirely } \\
\text { Aragonite }\end{array}$} & Unionidae $^{\mathrm{a}}$ & $\begin{array}{l}\text { Amblema costata, Elliptio dilitatus, Fusconia subrotunda, Fusconia } \\
\text { undata, Legumia recta latissima, Megalonaias gigantean, Pleurobema } \\
\text { cordatum, Plelhobasus cyphyus, Quadrula pustulosa, Quadrula } \\
\text { quadrula. [6] }\end{array}$ \\
\hline & Lampsilinae $^{\mathrm{a}}$ & $\begin{array}{l}\text { Actionaias carinate, Lampsilis anadontoides, Lampsilis ventricosa, } \\
\text { Leptodea fragilis, Obovaria subrotunda, Obliquaria reflexa, Proptera } \\
\text { alata, Ptychobranchus fasciolaris, Trucilla donaciformis. [6] }\end{array}$ \\
\hline & Anodontinae $^{\mathrm{a}}$ & Lasmigona complanata, Lasmigona costata, Strophitus rugosus. [6] \\
\hline & Arcidae & Anadara granosa. [4] \\
\hline $\begin{array}{l}\text { Calcite and } \\
\text { Aragonite }\end{array}$ & Strombidae & Strombus gigas Linnaeus [6] \\
\hline $\begin{array}{l}\text { Entirely } \\
\text { calcite }\end{array}$ & Ostreidae & Ostrea $s p[6]$ \\
\hline
\end{tabular}

${ }^{a}$ The samples were taken from the Muskingum River in Ohio.

${ }^{b}$ The samples were taken from Kota Samarahan, Sarawak, Malaysia

This research is to determine the polymorph and crystalline structure of the calcium carbonate from the clamshell of Polymesoda bengalensis. Knowing the polymorph is very important because different polymorph has different potential application. Aragonite $\mathrm{CaCO}_{3}$ from seafood shell is applicable for removing heavy metal from polluted wastewater. It is able to adsorp lead and cadmium better than calcite $\mathrm{CaCO}_{3}[26,27]$ Aragonite $\mathrm{CaCO}_{3}$ is also biocompatible compared to other elements such as $\mathrm{CaO}$ and $\mathrm{MgO}$ [28]. 


\section{Materials and methods}

\subsection{Sample collection}

The muddy clam shells were scrubbed to remove grits on the shell. Then, the shells were soaked in the boiled water for 15 minutes to allow the shell and flesh to be separated easily. After that, the shells were dried in the oven at a temperature of $85^{\circ} \mathrm{C}$ for 6 hours. One of the shells was cut as shown in Figure 1 by using a Struers cutting machine. A grinding process was performed on the cut surface area by applying grit paper of grade 1000 before the shells were washed and dried again in the oven for 8 hours. Finally, the surfaces of outer, inner and sectional parts of the specimen were goldsputtered and then mounted under the SEM for morphology observation.

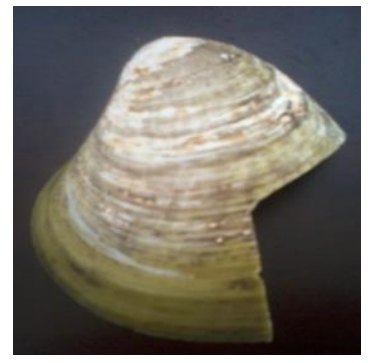

Figure 1. Sample of Polymesoda bengalensis shell

\subsection{Preparation of the shell powder}

The small particle was produced by crushing the dried shell using mortar and pestle. To transform the particles into a powder form, the particles were ground using a blender. The powders were then sieved through aperture size of $63 \mu \mathrm{m}$. Only powder passed through $63 \mu \mathrm{m}$ sieve size was packed and sealed in a polyethylene plastic bag for morphology and polymorph analysis.

\subsection{Analysis}

(1) Polymorph, elemental and morphological test

The type of crystal of the shell powder was identified using PANalytical X'Pert PRO powder diffractometer using Copper anode in wavelength of $0.154 \mathrm{~nm}$ and taking $2 \theta$ in the range of $0^{\circ}$ to $80^{\circ}$ and step size of $0.01^{\circ}$. The data was analysed by X'Pert HighScore software. For morphological study, clam shell and its powder were first coated with gold using gold sputter machine before it was observed using SEM (model Hitachi S3400N). The elemental study was performed at three different areas of the shell namely inner, cross-section and outer parts using energy dispersive X-ray analyser (EDX-Horiba EMAX model) at 10-15 kV.

(2) Powder size and specific surface area measurement

The powder mean size was determined using particle size analyzer (model Malvern Mastersizer 2000). $5 \mathrm{~g}$ clam shell powder was mixed in the distilled water and stirred to obtain the homogeneity and to avoid the particle settling. Laser diffractor was used to measure the mean size of the powder. The specific surface area of the powder was measured using Brunauer-Emmett-Teller (BET) apparatus by applying the liquid nitrogen, degassed at $100{ }^{\circ} \mathrm{C}$ for 24 hours and at $10^{-5} \mathrm{mmHg}$ pressure. 


\section{Results and Discussion}

\subsection{Identification of type of polymorph by XRD analysis}

Figure 2 demonstrates the XRD patterns of Polymesoda bengalensis shell powder. It shows that all peaks matched with $\mathrm{CaCO}_{3}$ [29] from $0^{\circ}$ to $80^{\circ}$ of $2 \theta$. The dominant peak of $2 \theta$ correlated with (hkl) indices of (111), (102), (201) and (122) were found at $26.192^{\circ}, 27.46^{\circ}, 33.090^{\circ}$ and $45.823^{\circ}$, respectively. From these indices, it can be said that the polymorph of $\mathrm{CaCO}_{3}$ is aragonite according to ICSD collection code no. 157994. Bragg's equation is used to determine the crystal structure and polymorph of the crystal.

$$
d_{k k l}=\frac{\lambda}{2 \sin \theta}
$$

Where $\mathrm{d}$ is a lattice interplanar spacing of the crystal, $\theta$ is an $\mathrm{x}$-ray incidence angle (Bragg angle) and $\lambda$ is a wavelength of the characteristic $x$-ray.

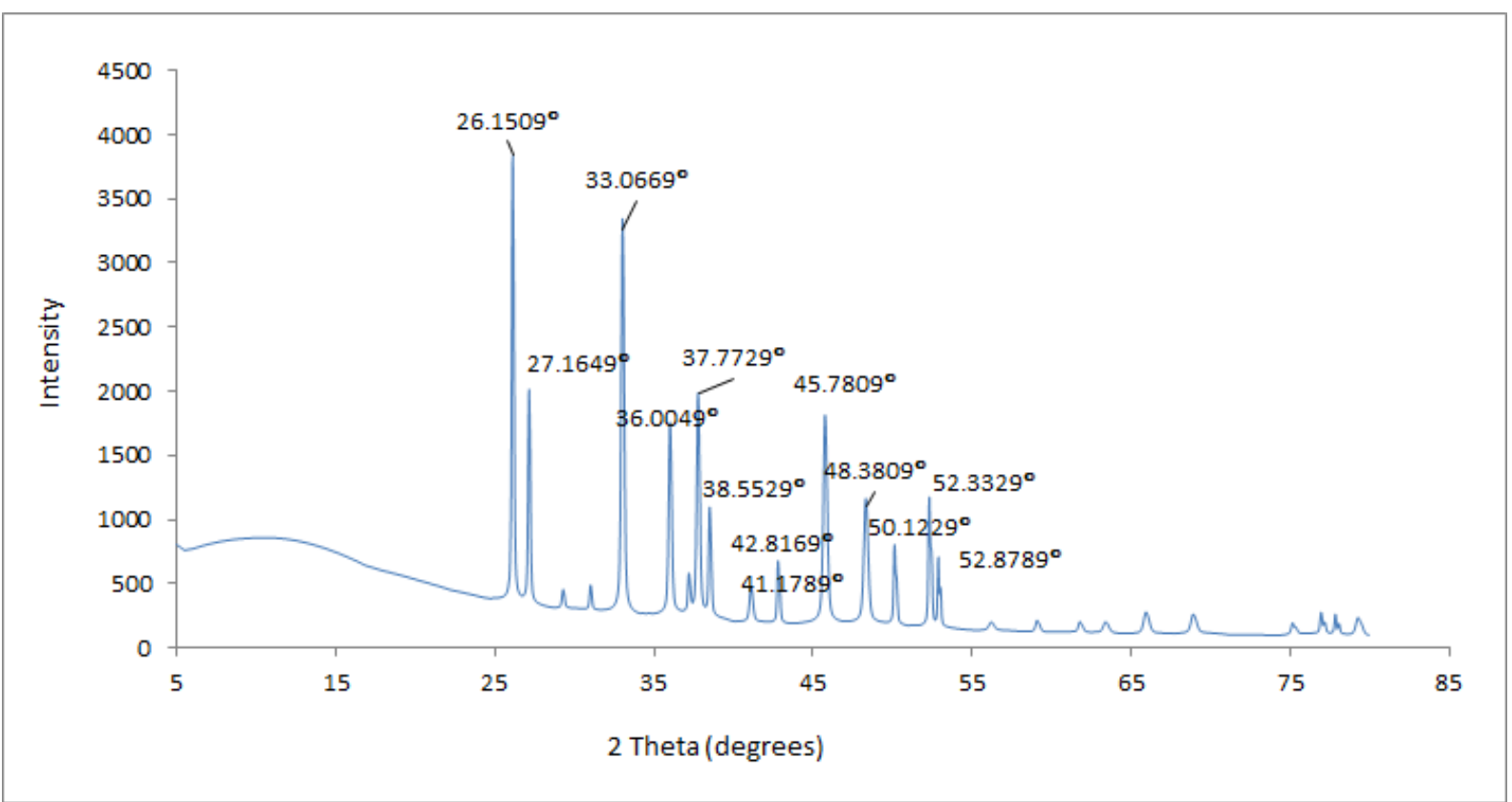

Figure 2. Diffractogram of Polymesoda bengalensis shell powder.

Aragonite $\mathrm{CaCO}_{3}$ has high potential for biomaterial. It can be used for bone repair due to the its density is higher than commercial $\mathrm{CaCO}_{3}$ [12]. Nanocrystalline aragonite $\mathrm{CaCO}_{3}$ impregnated with hydraulic acid allows young hyaline cartilage regeneration results in animal bone. This shows that the scaffold made from aragonite $\mathrm{CaCO}_{3}$ could be useful for treating both chondral and osteochondral defect in human bone [30].

Aragonite $\mathrm{CaCO}_{3}$ can be an agent to remove heavy metals in wastewater such as cadmium, cobalt, copper, lead and zinc. Ground aragonite $\mathrm{CaCO}_{3}$ powder has high capacity to adsorp heavy metals, exceed the capacity level gained by chitin and chitosan [31]. The submicron carbonate structure in the shell powder provide the organic matrix for the heavy metal adsorption. Compared to calcite $\mathrm{CaCO}_{3}$, aragonite $\mathrm{CaCO}_{3}$ is more effective to adsorb lead in wastewater [32]. 


\subsection{Surface morphology by SEM}

Figure 3 illustrates that most of the particles in aragonite clam shells were in the form of rodlike. The powder was also arranged in similar direction. Interestingly, it was found to be attracted to each other due to high surface energy [33,34]. High surface energy is normally occurred between untreated $\mathrm{CaCO}_{3}$ particles.

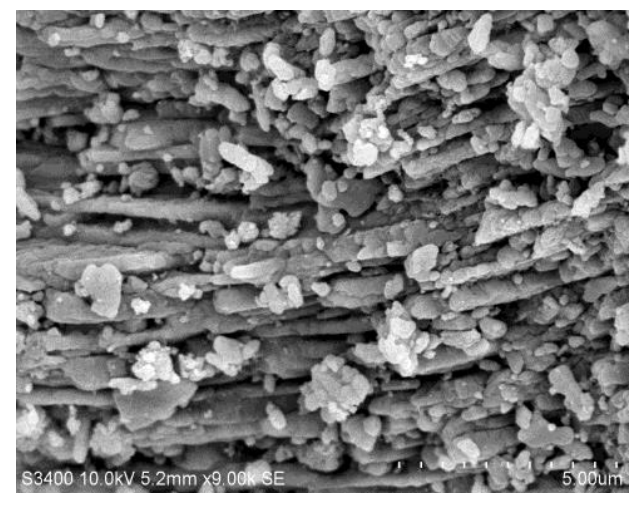

Figure 3. SEM image of the surface morphology of Polymesoda bengalensis clam shell particle

Figure 4(a) shows that the outer surface of the shell is rough with the presence of concentric rings. The colour is green but the umbo at the ventral is found to be eroded. On top of that, the inner surface of the shell is shiny in white colour except at the dorsal part where the muscles attached is yellow. The sectional part of the shell in Figure 4(b) reveals that the aragonite layers were arranged in the form of cross-lamellar structure. Similar arrangement was also found in a mollusc shell of S. Marginatus [35]. It is fundamental to note that crossed-lamellar structure with various levels was also found in lamellar bone, which can be used to reduce the anisotropy, thus that material may perform satisfactorily under various loading conditions [36]. Figure 4(c) highlights the discovery of a porous structure at the ventral part of an outer surface of the shell. Different structure was detected at dorsal part of outmost surface of the shell as shown in Figure 4(d). The structure was finer than the ventral part. The aragonite structure was clearly observed at a shiny white colour surface of the inner part. At the yellow-coloured area, the coarser particle with longer rod-like aragonite was detected but not in the white area as shown in Figure 4(f). 
(a)
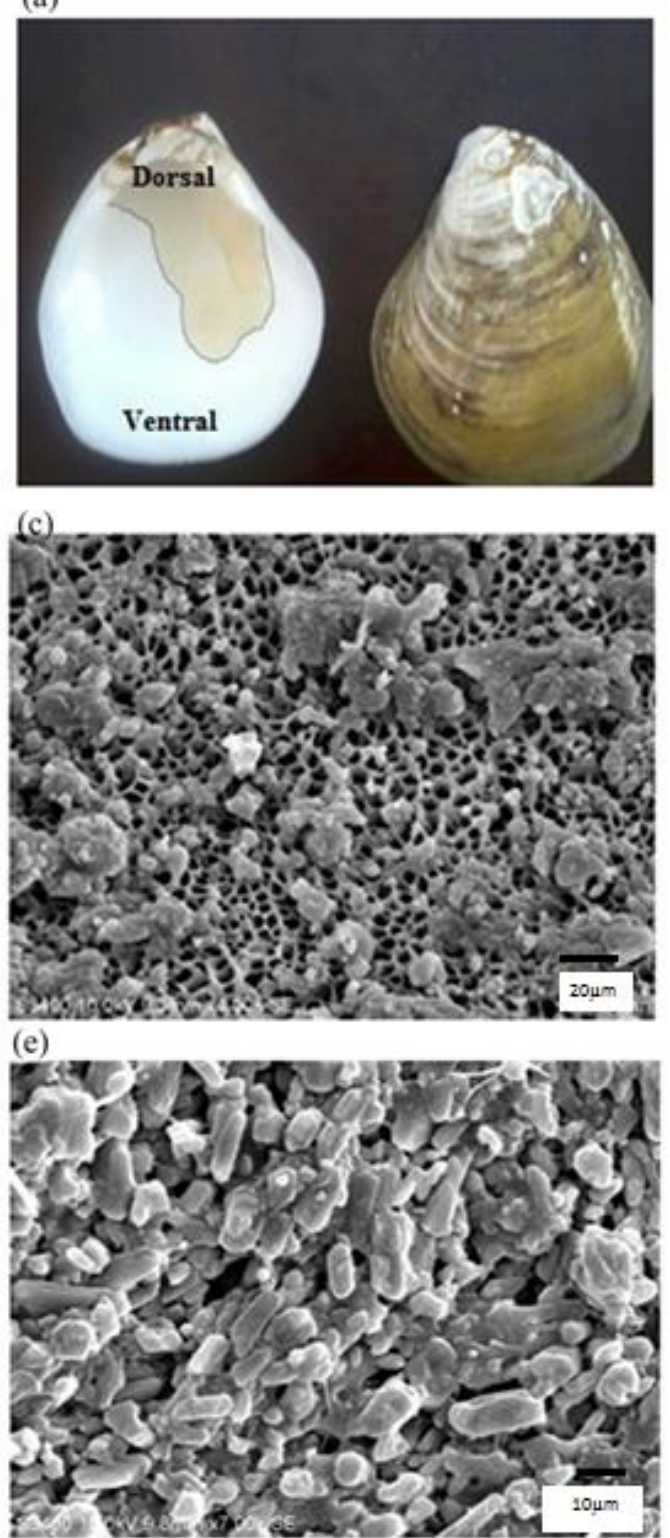

(b)
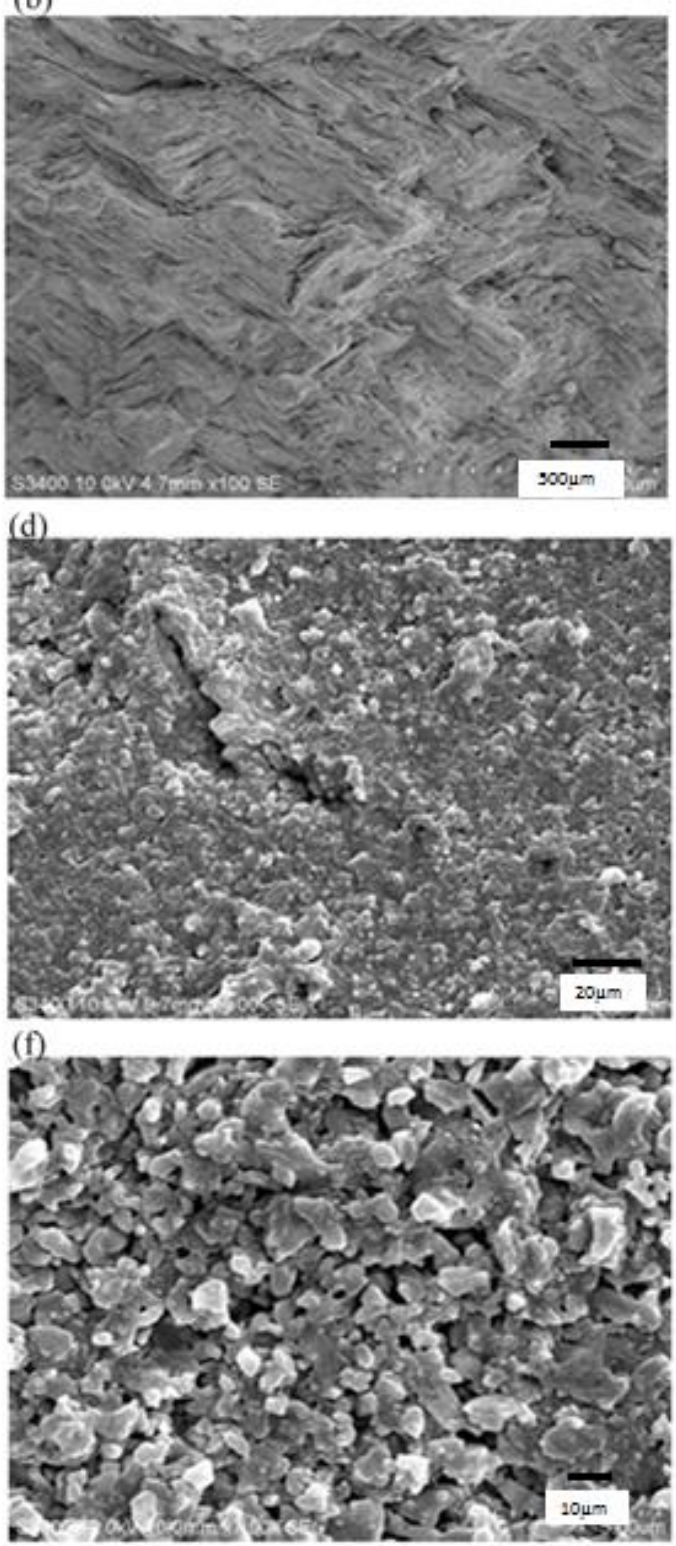

Figure 4. Image of (a) inner and outmost surfaces, and SEM images of the (b) cross-sectional area, (c) ventral part of the outmost surface, (d) dorsal part of the outer surface, (e) yellow area of the dorsal part at the inner surface, and (f) white area of the dorsal part at the inner surface of the Polymesoda bengalensis shell

\subsection{Elemental analysis by EDX spectrum}

Table 2 shows the EDX results of elemental content of the powder derived from Polymesoda bengalensis shells. The findings revealed that the powder, which was less than $63 \mu \mathrm{m}$, contained pure calcium carbonate without any trace elements. The calcium carbonate powder was rich in oxygen and calcium. The carbon content in this shell is $14.18 \%$ compared to only $11.91 \%$ in commercial calcium carbonate [4]. Figure 5 shows the spectrums at spot 1 to 3 of the shell. 
Table 2. Elemental content of particle derived from Polymesoda bengalensis clam shell

\begin{tabular}{ccccc}
\hline Spot & $\begin{array}{c}\mathbf{C} \\
(\boldsymbol{\%})\end{array}$ & $\begin{array}{c}\mathbf{O} \\
(\boldsymbol{\%})\end{array}$ & $\begin{array}{c}\text { Ca } \\
(\boldsymbol{\%})\end{array}$ & $\begin{array}{c}\text { Total } \\
(\boldsymbol{\%})\end{array}$ \\
\hline Spot 1 & 11.23 & 33.69 & 55.08 & 100 \\
Spot 2 & 15.94 & 50.63 & 33.43 & 100 \\
Spot 3 & 15.38 & 45.37 & 39.25 & 100 \\
Mean & 14.18 & 43.23 & 42.59 & \\
Std. Deviation & 2.58 & 8.67 & 11.20 & \\
Max & 15.94 & 50.63 & 55.08 & \\
Min & 11.23 & 33.69 & 33.42 & \\
\hline
\end{tabular}
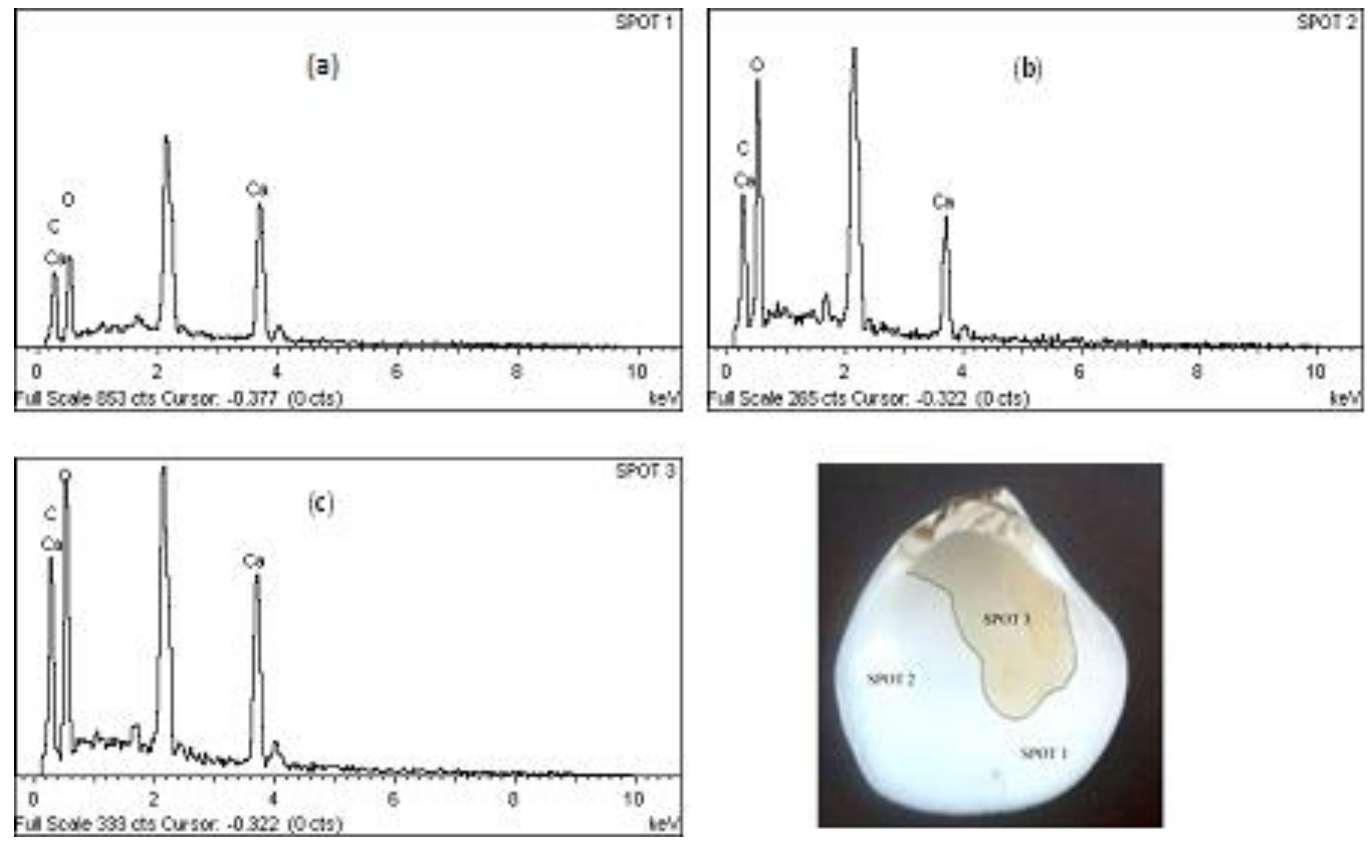

Figure 5. EDX spectrum at spot 1,2 and 3 at the inner surface of the clam shell 


\subsection{Mean diameter size and specific surface area}

Table 3 shows the mean diameter size and the surface area of the clam shell powder. It shows that the finer the size of the powder, the more specific area of the powder. Larger specific surface area produced higher surface energy. This further explains why the finer particles tend to attract among themselves and produce particle cluster. The excess energy at the surface of the finer particles compared to bulk is higher than course particles. The active bond between the particles create the formation of particles cluster. Coarser particles have less specific surface area because the excess surface energy is lower than bulk particles. Therefore, coarser particles normally less tendency to coagulate or agglomerate.

Agglomeration is uninvited in particulate filler composites. The particle cluster is a point of where failure starts in composite material due to higher stress concentration. To avoid this in nanoparticle reinforced polymer matrix composites, the $\mathrm{CaCO}_{3}$ particles are normally treated with stearic acid [30]. The reduction of surface energy minimises particle-particle interaction, thus encourages better homogeneity of filler in the polymer matrix.

For pharmaceutical tablet, particles agglomeration is very crucial. The compactness of the tablet is higher if the powder is finer. The tablet strength is controlled by the surface energy or particles bonding. Therefore, contradicted with particulate composite system, the agglomeration is invited in pharmaceutical tablet.

Table 3. Particle sizes and specific particle surface areas of the investigated particle

\begin{tabular}{cc}
\hline Particle size $(\boldsymbol{\mu m})$ & Specific surface area $\left(\mathbf{m}^{2} / \mathbf{g}\right)$ \\
\hline $\mathbf{2 9 . 8 4}$ & 7.143 \\
$\mathbf{3 5 . 0 6}$ & 2.217 \\
$\mathbf{4 6 . 3 0}$ & 0.589 \\
\hline
\end{tabular}

\section{Conclusions}

Aragonite, which is a valuable mineral polymorph, was detected in the clam shell of Polymesoda bengalensis species by XRD analysis. The result appeared to be well substantiated by applying SEM, where rod-like aragonite was observed, and its elements were found to be rich in oxygen and calcium without any detection of trace elements. The specific surface area of the powder was found to be increased as the particle size decreased.

\section{Acknowledgement}

The authors wish to thank to Universiti Malaysia Sarawak (UNIMAS) for providing financial support and research facilities. This research was financially supported by Special Short Term Grant (F02/SpSTG/1384/16/26) of Universiti Malaysia Sarawak. 


\section{References}

[1] Xiang, L., Xiang, Y., Wen, Y. and Wei, F. (2004). Formation of $\mathrm{CaCO}_{3}$ Nanoparticles in the Presence of Terpineol, Materials Letters; Vol.58, No.6, 959-965.

[2] Rothon, R.N. (2007). The High Performance Fillers Market and the Position of Precipitated Calcium Carbonate and Silica, Proceedings of High Filler 2007, Hamburg, Germany.

[3] Manoli, F. and Dalas, E. (2000). Spontaneous Precipitation of Calcium Carbonate in the Presence of Ethanol, Isopropanol and Diethylene Glycol. Journal of Crystal Growth; Vol.218, No.2, 359-364.

[4] Islam, K.N., Bakar, M.Z.B.A., Noordin, M.M., Hussein, M.Z.B., Rahman, N.S.B.A. and Ali, M.E. (2011).. Characterisation of calcium carbonate and its polymorphs from cockle shells (Anadara granosa), Powder Technology, Vol.213, No.1-3, 188-191.

[5] Lee, S.W,. Kim, G.H. and Choi, C.S. (2008). Characteristic crystal orientation of folia in oyster shell, Crassostrea gigas. Materials Science and Engineering: C, Vol.28, No.2, 258-263.

[6] Compere, Jr. and EL Bates, J.M. (1973). Determination of calcite: aragonite ratios in mollusc shells by infrared spectra. Limnology and Oceanography, 326-331.

[7] Lutts, A., Grandjean, J. and Grégoire, C. (1960). X-ray diffraction patterns from the prisms of mollusk shells. Archives Of Physiology And Biochemistry, Vol.68, No.5, 829-831.

[8] Mann, S. (2002). Biomineralization: principles and concepts in bioinorganic materials chemistry. Vol. 5, Oxford University Press, USA.

[9] Kennedy, W.J., Taylor, J.D. and Hall, A. (1969). Environmental and biological controls on bivalve shell mineralogy. Biological Reviews, Vol.44, No.4, 499-530.

[10] Taylor, J.D. (1969). The shell structure and mineralogy of the Bivalvia. Introduction, NuculaceaTrigonacea. Bull. Br. Mus. Nat. Hist.(Zool.), Vol.3, 1-125.

[11] Stupp, S.I. and Braun, P.V. (1997). Molecular manipulation of microstructures: biomaterials, ceramics, and semiconductors. Science, Vol.277, No.5330, 1242-1248.

[12] Lee, I., Han, S.W., Choi, H.J. and Kim, K. (2001). Nanoparticle-directed crystallization of calcium carbonate. Advanced Materials, Vol.13, No.21, 1617.

[13] Ma, H. and Dai, T. (2001). The First Discovery of Vaterite in Lusterless Fresh Water Pearls of Leidian, Zhejiang. Acta Mineral. Sin, Vol.21, 153-157.

[14] Chen, J. and Xiang, L. (2009). Controllable synthesis of calcium carbonate polymorphs at different temperatures. Powder Technology, Vol.189, No.1, 64-69.

[15] Hu, Z. and Deng, Y.(2004). Synthesis of needle-like aragonite from calcium chloride and sparingly soluble magnesium carbonate. Powder Technology, Vol.140, No.1, 10-16.

[16] FAO. (2011). National aquaculture sector overview: Malaysia. Food and Agriculture Organization.

17] Hamli, H., Idris, M., Hena, M.K.A. and Wong, S. (2012).Taxonomic Study of Edible Bivalve from Selected Division of Sarawak, Malaysia. International Journal of Zoological Research, Vol.8, No.1, 52-58.

[18] Poutiers, J. (1998)Gastropods: The Living Marine Resources of the Western Central Pacific, Carpenter, KE and VH Niem (Eds.). FAO., USA., ISBN, 92-5.

[19] Nakao, S., Nomura, H. and Satar, M.K.B.A.(1989). Macrobenthos and Sedimentary Environments in a Malaysian Intertidal Mudflat of the Cockle Bed, Bulletin of the Faculty of Fisheries Hokkaido University HOSGAD, Vol.40, No.4.

[20] Ong, C., Yusoff, K., Yap, C.K. and Tan, S.G. (2009). Genetic Characterization of Perna viridis L. in Peninsular Malaysia Using Microsatellite Markers, Journal of Genetics, Vol.88, No.2, 153-163.

[21] Yunus, K., Suhaimi, M., Zahir, M., John, A., Abdurahman, S.W., Khan Chowdhury, A.J., Saad, S., AlBarwani, S.M. and Goddard, J.S. (2010). Determination of Some Heavy Metal Concentrations in Razor Clam (Solen Brevis) from Tanjung Lumpur Coastal Waters, Pahang, Malaysia, Pakistan Journal of Biological Sciences, Vol.13, No.24, 1208-1213. 
[22] Kanakaraju, D., Ibrahim, F. and Berseli, M.N. (2008). Comparative Study of Heavy Metal Concentrations in Razor Clam (Solen Regularis) in Moyan and Serpan, Sarawak, Global Journal of Environmental Research, Vol.2, No.2, 87-91.

[23] Mohamad Yusoff, N.A. and Mohd Long, S. (2011). Preliminary Study on the Accumulation of Heavy Metal Concentration in Edible Mollusk from Sungai Sematan Estuary, Research Bulletin Faculty of Resource Science and Technology Universiti Malaysia Sarawak, Vol.1, 5-6.

[24] Lee, Y.H., Islam, S.M.A., Hong, S.J., Cho, K.M., Heo, J.Y., Kim, H. and Yun, H.D. (2010). Composted Oyster Shell As Lime Fertilizer is more Effective than Fresh Oyster Shell, Bioscience, Biotechnology, and Biochemistry, 1006282020-1006282020.

[25] Archer, M. (2004). Shellfish Waste Disposal and Opportunities for by-Products, 1-27.

[26] Cubillas, P., Köhler, S., Prieto, M., Chaïrat, C. and Oelkers, E.H. (2005). Experimental Determination of the Dissolution Rates of Calcite, Aragonite, and Bivalves, Chemical Geology, Vol.216, No.1, 59-77.

[27] Godelitsas, A,. Astilleros, J.M., Hallam, K., Harissopoulos, S. and Putnis, A. (2003). Interaction of Calcium Carbonates with Lead in Aqueous Solutions, Environmental Science \& Technology, Vol.37, No.15, 33513360.

[28] Hanna, W.A., Gharib, F.E. and Marhoon, II. (2011). Characterization of ceramic Filled Polymer Matrix Composite Used for Biomedical Applications, Journal of Minerals and Materials Characterization and Engineering, Vol.10, No.12, 1167.

[29] Pokroy, B., Fieramosca, J., Von Dreele, R., Fitch, A., Caspi, E. and Zolotoyabko, E. (2007). Atomic Structure of Biogenic Aragonite, Chemistry of Materials, Vol.19, No.13, 3244-3251.

[30] Kon, E., Filardo, G., Robinson, D., Eisman, J., Levy, A., Zaslav, K., Shani, J. and Altschuler, N. (2014). Osteochondral Regeneration Using a Novel Aragonite-Hyaluronate Bi-Phasic Scaffold in a Goat Model, Knee Surgery, Sports Traumatology, Arthroscopy, Vol.22, No.6, 1452-1464.

[31] Yan-jiao, G. (2011). Cadmium and Cobalt Removal from Heavy Metal Solution Using Oyster Shells Adsorbent, In Consumer Electronics, Communications and Networks (CECNet), International Conference on. 2011. IEEE.

[32] Tudor, H.E., Gryte, C.C. and Harris, C.C. (2006). Seashells: Detoxifying Agents for Metal-Contaminated Waters, Water, Air, and Soil Pollution, Vol.173, No.1-4, 209-242.

[33] He, H., Li, K., Wang, J., Sun, G., Li, Y. and Wang, J. (2011). Study on Thermal and Mechanical Properties of Nano-Calcium Carbonate/Epoxy Composites, Materials \& Design, Vol.32, No.8, 4521-4527.

[34] Zhang, H., Tang, L.C., Zhang, Z., Friedrich, K. and Sprenger, S. (2008). Fracture Behaviours of in situ Silica Nanoparticle-Filled Epoxy at Different Temperatures, Polymer, Vol.49, No.17, 3816-3825.

[35] Neves, N.M. and Mano, J.F. (2005). Structure/Mechanical Behavior Relationships in Crossed-Lamellar Sea Shells. Materials Science and Engineering: C, Vol.25, No.2, 113-118.

[36] Weiner, S., Addadi, L. and Wagner, H.D. (2000). Materials Design in Biology, Materials Science and Engineering: $C$, Vol.11, No.1, 1-8. 